\title{
Vegetable Seed Bed Preparation on Phosphatic Clays 1
}

\author{
E.A. Hanlon, G.J. Hochmuth, L. Shaw, and C. Riddle ${ }^{2}$

\section{Introduction}

This document addresses tillage associated with vegetable production on reclaimed phosphatic clays and summarizes the research findings from the Mined Lands Research/Demonstration Project (MLRDP), a cooperative project involving the University of Florida Institute of Food and Agricultural Sciences (UF/IFAS), Florida Institute of Phosphate Research (FIPR), the Polk County Board of Commissioners, and the phosphate industry. This project functioned from 1985 through 1994.

This document is intended for growers, land managers, and mining industry land-use planners and assumes a familiarity with basic soil tillage and vegetable horticultural processes.

The phosphatic clay resource is a by-product of phosphate mining in central Florida. This resource currently occupies approximately 100,000 acres. During active mining operations, the clay by-product is hydraulically pumped to impoundment areas where the clay settles out and the water is decanted for recycling within the mining operations. Upon cessation of mining operations, the phosphatic clay site is reclaimed to standards set by the state of Florida. Currently a natural systems model is used for declaring the site as reclaimed. However, the phosphatic clay resource has many qualities such as high water-holding capacity and high fertility. To be successfully farmed, phosphatic clay must be treated differently than the more traditional approach used for vegetable production with sandy soils of the Florida peninsula.

While tillage is important by itself, decisions regarding tillage should be made as a part of a comprehensive vegetable-production management plan, which includes factors such as: soil type, crop, irrigation, drainage and other hydraulic properties, market windows, and growing season. Decisions concerning tillage should fit into, and be an integral part of, such a plan to be truly effective. For additional information on cropping systems, economics of a number of crops including vegetables, agronomic crops, and trees, please refer to the home page for electronic documents from UF/IFAS ( http://edis.ifas.ufl.edu/ ).

1. This document is SL223, a fact sheet of the Soil and Water Science Department, Florida Cooperative Extension Service, Institute of Food and Agricultural Sciences, University of Florida. Originally published as SS-MLR-4 in June 1993. Revised March 2005 as SL223. Visit the EDIS Web Site at http://edis.ifas.ufl.edu.

2. Edward A. Hanlon, professor, Soil and Water Science, Southwest Florida Research and Education Center, Immokalee, FL; George J. Hochmuth, professor and center director; Charles Riddle, senior biological scientist, North Florida Research and Education Center, Quincy, FL; and Lawrence Shaw, professor emeritus, Agricultural and Biological Engineering, Gainesville, FL; Florida Cooperative Extension Service, Institute of Food and Agricultural Sciences, University of Florida, Gainesville, FL 32611-0510.

The Institute of Food and Agricultural Sciences is an equal opportunity/affirmative action employer authorized to provide research, educational information and other services only to individuals and institutions that function without regard to race, color, sex, age, handicap, or national origin. For information on obtaining other extension publications, contact your county Cooperative Extension Service office. Florida Cooperative Extension Service/Institute of Food and Agricultural Sciences/University of Florida/Christine Taylor Waddill, Dean. 


\section{Clod Formation (Aggregation) in Phosphatic Clay}

Clods within the seedbed may decrease stand-establishment success, especially when direct seeding. Most of the tillage research at MLRDP was directed at the effects of clods on vegetable production. A portion of this research addressed tillage methods to minimize clod formation while additional work focused on clod-size reduction.

Soil texture is defined as the amounts of sand, silt, and clay within the soil. Finer textured soils have more clay and/or silt, while coarser textured soils contain more sand. Clods are formed through the process known as soil aggregation or the grouping of soil particles into larger masses. Finer textured soils are more likely to produce clods when tilled. Since phosphatic clay is dominated by the clay fraction, clod production can be expected to occur with tillage operations.

\section{Clod formation}

Two primary factors can be addressed by the grower before tillage of phosphatic clay. The primary factor controlling clod size is soil moisture within the depth of soil to be tilled. Wetter soil conditions will result in larger clods. Dryer soil conditions during tillage will produce smaller clods. In the case of phosphatic clay, soil moisture should be a major consideration in deciding if and when to till. Fine texture at the surface results in slow water infiltration into the phosphatic clay. Therefore, proper surface drainage is needed to reduce the incidence of waterlogged soil conditions, as well as to reduce the time during which the surface is too wet for field operations, such as following irrigation or rainfall.

A secondary factor is the amount of organic matter in the soil. As organic matter coats soil particles, these coated particles can be expected to aggregate. While this effect seems to be a negative for organic matter, it contributes to weak clod persistence.

\section{Clod persistence}

After clod formation due to tillage, both moisture and organic matter content can influence clod persistence. Once clods are dried and hard, considerable work must be done to break up the clods to produce and acceptable vegetable bed. However, organic matter holds moisture allowing much easier bed preparation. The persistence of clods in phosphatic clay is remarkably short with proper post-tillage management (discussed below). The maintenance of organic matter in all Florida soils used for commercial plant production is a wise investment, especially in phosphatic clay soils.

\section{Typical Phosphatic Clay Moisture Profile}

Phosphatic clays were reclaimed by reducing the water content of the clays until the surface could support normal crop-production activities. However, moisture levels rapidly increase with depth. For discussion purposes, a phosphatic clay profile can be divided theoretically into three zones or depths of differing moisture content (Figure 1). The first zone, roughly from the surface to 4 to 6 inches, remains the driest. Moisture is removed by evaporation or by transpiration from plants, and added by infiltration of irrigation water or rainfall. The second zone from approximately 4 to 6 inches to a depth of 10 to 12 inches is much higher in water content and is quite sticky in nature. Roots may penetrate this zone, but less water is lost through transpiration than from the surface zone. Recharge of water may occur from cracks, which open to the surface, or occur more slowly by upward capillary movement from wetter clay below. The third zone is the highest in water content and is usually found at 10- to 18-inch depth and may persist for the entire depth of the clay layer in the pond. This zone is waterlogged and contains few roots compared with the second zone.

These moisture zones, especially the first two zones, control the effectiveness of any tillage effort because of the formation of clods. Water content within the third zone is usually quite high; the clay acting much like a slow-flowing fluid. Deep tillage into this third zone is not recommended because of the fluid nature of the water-saturated phosphatic clay. Equipment may sink, getting mired or lost completely below the clay surface. These same dangers are increased for humans who inadvertently step into this fluid clay zone. 


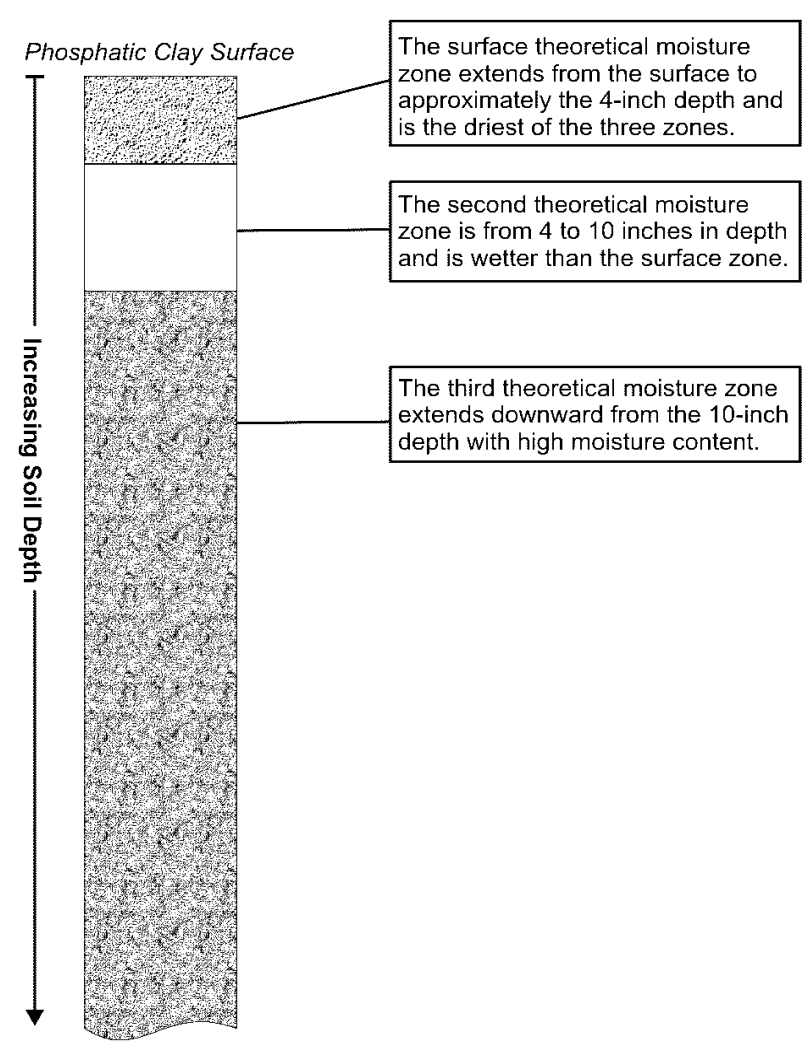

Figure 1. Theoretical moisture zones for use in understanding clod formation in reclaimed phosphatic clay.

Using these three theoretical moisture zones (Figure 1) can be quite helpful in understanding the formation of clods. If clay in the tillage operation comes only from the first zone, little additional clod formation will occur and any mechanical effort in this zone will usually cause clod size to decrease. For example, a shallow disking of relatively dry phosphatic clay will produce a small clod size. However, if material from both the first two zones is incorporated, the wetter material from the second zone will act as a binder for the drier surface material, and larger clods will result. This effect is enhanced by deeper tillage, which also turns over the upper soil profile, such as with moldboard or disk plowing. Such turning action will produce large clods whose size depends upon the length and shape of the tillage implement. It is not uncommon to produce clods of 16 to 18 inches in length using a 24-inch disk plow (Figure 2) with deeper tillage including the first and second zones.

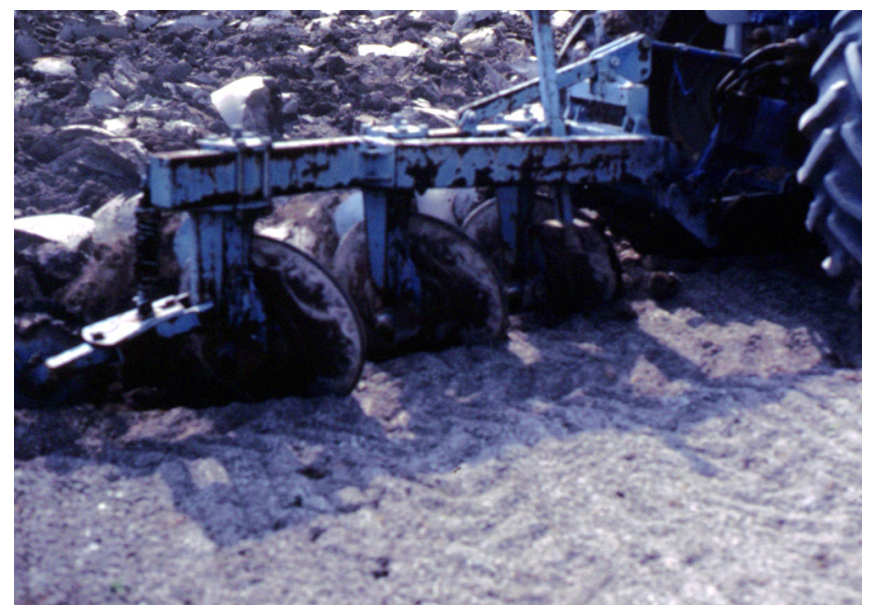

Figure 2. 24-inch disk plow turning phosphatic clay and forming large clods. Note the formation of clods (background) caused by the disk plow.

\section{No Measurable Compaction Zone Found in Phosphatic Clay}

Practices such as subsoiling are not necessary because much of the mechanical effort of tillage is absorbed by the wet nature of the third zone. Measurements with a recording penetrometer do not indicate the formation of a compaction zone, even after as many as ten passes of a disk harrow. Only one or two passes would be enough to form a compaction zone on sandy-textured soil. In phosphatic clay, the lack of a compaction zone formation will persist so long as the second and third zones remain wet.

\section{Disking operations}

Research at the MLRDP has shown that larger disks do not clog up as readily as smaller disks. Plowing operations using a disk plow are not effective below a depth of 6 to 8 inches (Figure 2). Because of the large clods formed in this operation, additional tillage is required. The benefits of plowing phosphatic clays are the same as those for other soils, i.e., plant-residue incorporation and pest control. Other benefits, such as reduced bulk density and reduced compaction (decreased soil bulk density) within the plowed zone, are only achieved through additional tillage operations needed to reduce clod size. No tillage pan or compaction zone has been found in phosphatic clays at the MLRDP. Disk harrowing works well on phosphatic clays. Since harrowing penetrates 4 to 6 inches in depth, little 
increase in larger clods is observed. Such tillage is often preferable to deeper tillage for this reason. Also, shallower tillage depth (and hence, drier phosphatic clay) means that clogging of the implement is less likely to occur.

\section{Rototilling}

The larger clods produced by plowing can be reduced by several passes of a vertical-shaft rototiller (Figure 3). The mixing and twisting action of this implement effectively breaks down clods in one to three passes. The moisture level of the clods will determine the number of passes: wetter clods require more passes. Use of this tool at MLRDP produced adequate vegetable beds for transplants, but often clod size was too large for direct seeding operations.

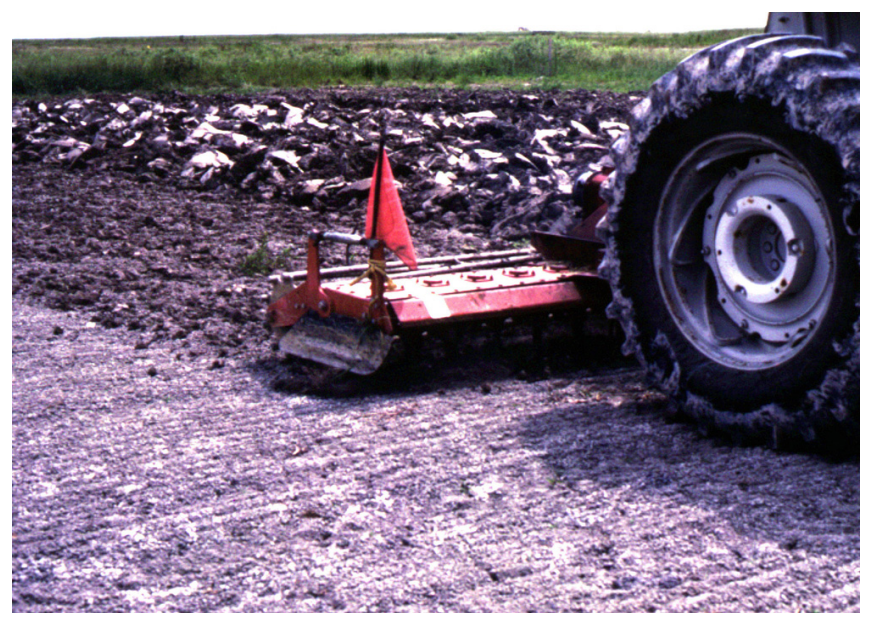

Figure 3. Vertical shaft rototiller on harrowed phosphatic clay. Note the size of clods produced from this machine and those from the disk plow in the background.

A horizontal-shaft rototiller was found to be more effective in producing an acceptable seedbed for vegetable production than multiple disk passes. The effectiveness of this type of rototiller depends upon the milling operation of the tines. Higher tine-rotation speed and low forward speed combine to provide fine particles in the bed. Good success in producing fine particles has resulted by rototilling the top of a false bed formed by a disk terracer (Figure 4 and Figure 5).

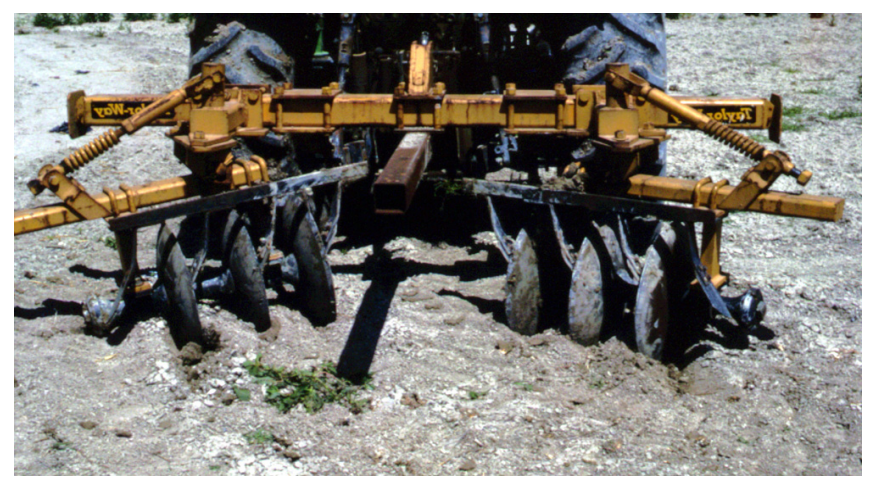

Figure 4. Terracer with gang disks set to form a false vegetable bed. Disks are 22-inch and depth is set between 4 to 8 inches. The outside disk sets have been removed to produce a false vegetable bed.

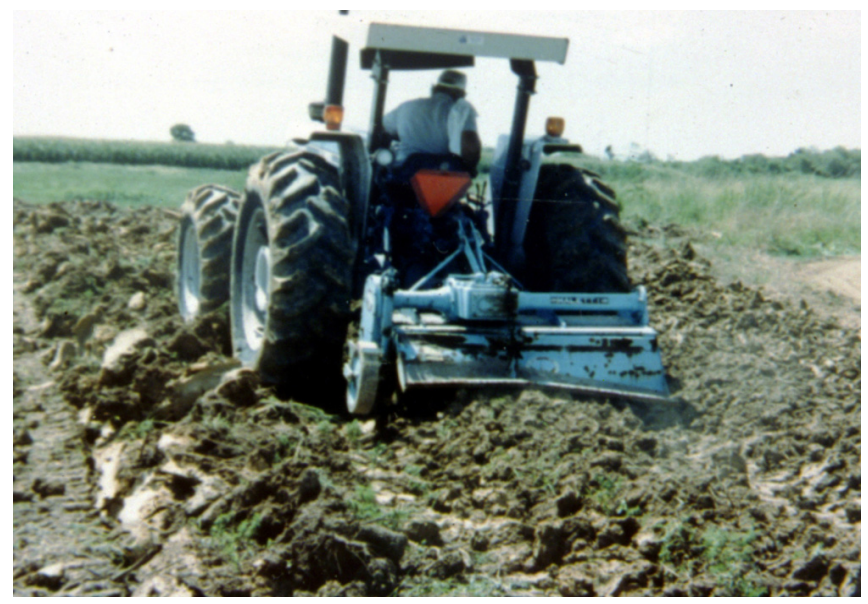

Figure 5. First pass of a horizontal-shaft rototiller on a false bed formed by the terracer. Note the reduction in clod size compared to the false bed to the left of the tractor.

\section{Bed Press/Polyethylene Mulch Operations}

A bed press is often needed to shape the phosphatic clay before covering it with polyethylene mulch. However, the press should be adjusted so as not to cut too deeply; i.e., into the second moisture zone. Because the press does not till the clay and may actually compress it, additional clods may be formed producing an unsatisfactory seedbed. Additional, unwanted clods may be formed by opening coulters, if the press is so equipped. Thus, most of the clod-size reduction must be done before using a press.

\section{Rotary Bedder: a New Tillage Tool}

Because of the difficulties in tilling the phosphatic clays with conventional equipment, 
research findings of tillage experiments were used to design a rotary bedder that would work with phosphatic clay. The rotary bedder was designed to follow initial land preparation, such as one or two passes of a disk harrow.

This rotary bedder consists of a horizontal shaft rototiller and two large, opposing helicoid screws mounted on a single shaft. The rototiller mills the surface producing small, fine particles. Then, the large screws move the particles from the inter-row areas behind the tractor wheels into the center, shaping the material into the final bed design. The rotary bedder produced a bed measuring 6 inches high by 36 inches wide (Figure 6).

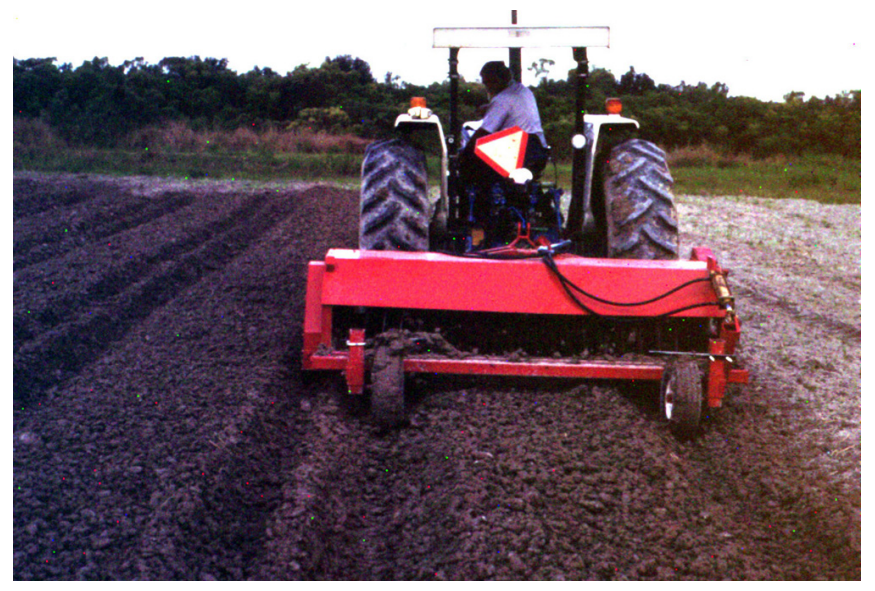

Figure 6. New rotary bedder using helicoid screws to form a raised vegetable bed in a single pass.

Trials showed that the implement produced excellent raised seed beds in one pass, even in wet surface conditions. However, the prototype was considered too slow for commercial field operations and no manufacturer has adapted the design. This implement was well designed and should be considered for development as additional reclaimed phosphatic clay areas are used for intensive agriculture.

\section{Irrigation/Rainfall for Bed Preparation}

After false beds are prepared, it is possible to allow wetting and drying to break down the clods to produce an acceptable seedbed. If rainfall alone is used, the process will require several months, depending upon the initial size of the clods and rainfall frequency. Overhead irrigation can greatly

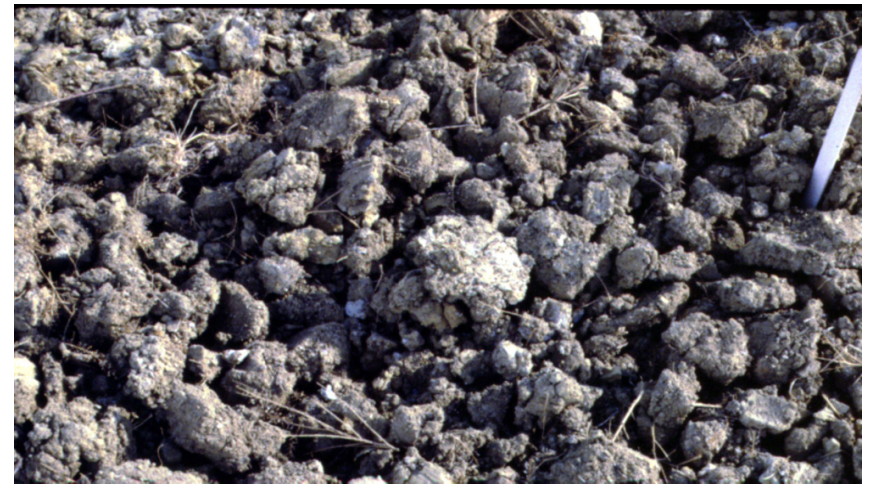

Figure 7. Large clods formed by creating a false bed with the terracer and one pass of a horizontal-shaft rototiller. The clods were allowed to mellow with natural rainfall at this point.

enhance the process, requiring as little as 1 to 3 weeks. Several cycles of 0.5 to 0.7 inches of water followed by several days of drying may be needed (Figure 7 and Figure 8).

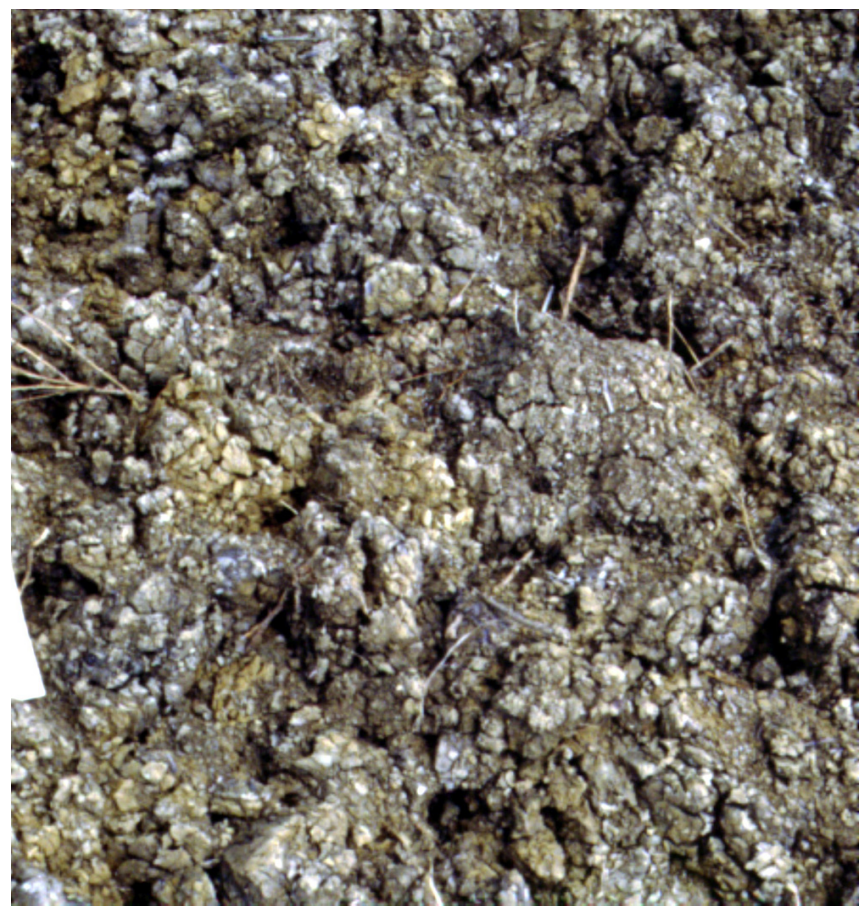

Figure 8. Same location after mellowing for 1 month. Note that larger clods have broken. Amount of precipitation was 1.7 inches.

After this so-called mellowing process is completed, only one pass of a horizontal-shaft rototiller (Figure 9) and bed pressing is required before applying polyethylene mulch. Alternatively, a version of the rotary bedder described above could supply the finishing tillage work after initial mellowing has occurred. Depending upon availability 
of irrigation water, this process may be more economical than tillage to reduce clod size and prepare suitable beds.

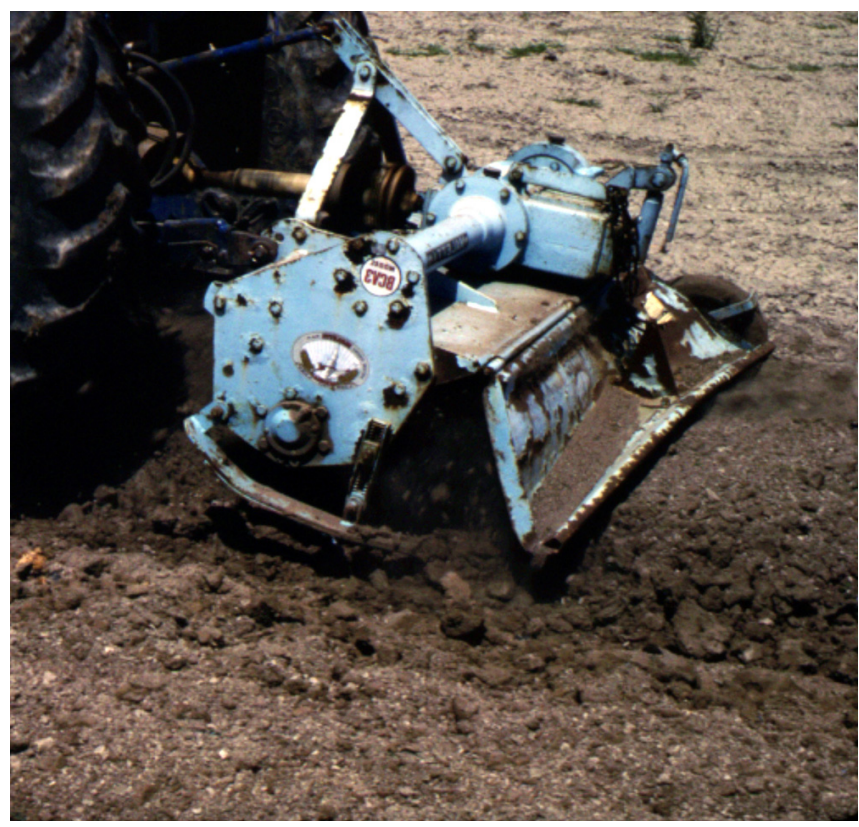

Figure 9. First pass of a horizontal-shaft rototiller on mellowed false bed (see Figure 8). The quality of the vegetable bed is acceptable for transplants and some seeding operations.

\section{Summary}

Reduction of clod size is the controlling factor in forming appropriate vegetable seedbeds. To accomplish this task, growers should select the least energy intensive tillage method available to them. Research results indicate that formation of false beds using a terracer followed by either rototilling the false bed tops or by the use of wetting and drying cycles appear to be the most effective approaches. 